\title{
Örtüaltı domates yetiştiren üreticilerin girdi kullanım kararlarının analitik hiyerarşi süreci ile analizi
}

\author{
Analysis of farmers input usage decisions in greenhouse tomato production by \\ analytical hierarchy process
}

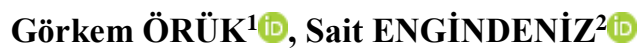 \\ ${ }^{1}$ Siirt Üniversitesi, Ziraat Fakültesi, Tarım Ekonomisi Bölümü, 56100, Siirt \\ ${ }^{2}$ Ege Üniversitesi, Ziraat Fakültesi, Tarım Ekonomisi Bölümü, 35040, İzmir
}

Sorumlu yazar (Corresponding author): G. Örük, e-posta (e-mail): gorkem.ozturk@siirt.edu.tr

Yazar(lar) e-posta (Authore-mail): sait.engindeniz@ege.edu.tr

\section{MAKALE BİLGİSI}

Alınış tarihi 12 Mart 2019

Düzeltilme tarihi 04 Eylül 2019

Kabul tarihi 05 Eylül 2019

\section{Anahtar Kelimeler:}

Domates

Örtüaltı

Girdi kullanımı

Karar analizi

\section{ÖZ}

$\mathrm{Bu}$ çalışmada, Muğla ilinde örtüaltı domates yetiştiren üreticilerin girdi kullanım kararlarındaki öncelikleri analitik hiyerarşi yöntemiyle saptanmıştır. Araştırmanın verileri oransal örnekleme ile 93 üreticiden yüz yüze anket yöntemiyle derlenmiştir. Sonuç olarak, örtüaltı domates üretiminde üreticilerin girdi kullanım kararında en fazla etkili olan kriterin fiyat olduğu tespit edilmiştir. Daha uygun fiyatlı girdi temini ve pazarlamada etkinlik sağlamak için üreticilerin örgütlenmelerine ihtiyaç duyulmaktadır. Üreticiler girdi kullanımına karar verirken dikkate aldıkları en önemli girdinin fide olduğu saptanmıştır. Girdi kullanım tercihinde ise üreticiler önceliği kimyasal girdilere vermektedir.

\section{ARTICLE INFO}

\section{Received 12 March 2019}

Received in revised form 04 September 2019

Accepted 05 September 2019

\section{Keywords:}

Tomato

Greenhouse

Input usage

Decision analysis

\begin{abstract}
In this study, the priorities of farmers who grow greenhouse tomato in Muğla district, on input usage decisions in greenhouse tomato production were determined by analytical hierarchy method. Data of this research were collected from 93 farmers with face to face survey method by using proportional sampling method. In conclusion, price is the most significant criteria on input usage decision of greenhouse tomato production. In order to obtain more affordable input and to provide efficiency in marketing, producers should be organized. Seedling is the most important input on input usage decision of greenhouse tomato production. In terms of input usage preference, the highest priority of farmers was chemical inputs.
\end{abstract}

\section{Giriş}

Tarımsal üretim karmaşı bir yapıya sahiptir. Üreticilerin hangi ürünleri, hangi yöntemle ve ne miktarda üreteceklerine böylesi karmaşık yapı içinde karar vermeleri gerekmektedir. Bu kararlar, tarımın teknik konularını, tarımsal üretim planlamasını ve bunun gerektirdiği tarımsal faaliyetlerin kayıt altına alınmasını kapsamaktadır. Bu bağlamda, üreticilerin karar önceliklerinin belirlenmesi önem arz etmektedir (Günden ve Miran 2008a).

Ürün deseninin ve girdi kullanım düzeylerinin belirlenmesi, pazarlama stratejisinin saptanması, üretim tekniklerinin seçimi ve değişen çevre koşullarına uyum bir dizi karar almayı gerektirmektedir. Bu tür kararlar çoğunlukla risk ve belirsizlik ortamında alınmaktadır. Üreticiler hava koşulları, piyasa, fiyat gibi belirsizliklerle karşı karşıya bulunmaktadır. Dolayısıyla işletmeler kararlarını verirken, gelecekte ne olacağını kesin olarak bilememektedirler. Bu nedenle geçmiş verilere dayanan geleceğe yönelik kestirimler üretim kararlarında yol göstermektedir. Böylelikle herhangi bir işletmeci öznel yargıları ile üretim kararlarına yön vermektedir. Elde geleceğe yönelik ne kadar fazla bilgi varsa alınacak kararların doğruluk derecesi de o kadar fazla olacaktır. Alınan kararın sonucunun iyi olup olamayacağı büyük ölçüde uygulamaya ve üretici becerisine bağlıdır (Işın 2000).

Tarımla ilgili karar analizlerinde sıklıkla kullanılan yöntemlerden biri de Analitik Hiyerarşi Prosesidir (AHP). Çok kriterli karar verme yöntemlerinden biri olan AHP bugüne kadar birçok farklı alanda çeşitli karar problemlerine uygulanmıştır (Korpela ve ark. 2007; Ahn ve Choi 2008; Günden ve Miran 
2008b; Aguilar-Lasserre ve ark. 2009; Arslan 2009; Çobanoğlu ve Işın 2009; Arslan 2010; Büyüközkan 2012; Quezada ve ark. 2014; Aydın ve ark. 2016; Günden 2016; Bostancığlu ve Önder 2018). Günden ve Miran (2008a) yürüttükleri çalışmada teknik yardım alma, planlama ve kayıt tutma gibi temel işletmecilik konularında çiftçilerin karar önceliklerini ve bu kararların alınmasında destek beklediği kurumların tercih derecelerini belirlemişlerdir. Çiftçilerinin işletmecilik karar önceliklerinde planlamanın ilk sırada olduğu saptanmıştır. Ömürbek ve ark. (2013) Isparta ilinde AHP yöntemini kullanarak 7 ilçe 5 farklı kritere göre (konum, çevresel faktörler, işgücü, yatırım maliyetleri, yasalar) karşılaştırılarak optimum kuruluş yerini belirlemeye çalışmışlardır. İdeal kuruluş yeri ise Yalvaç ilçesi olarak saptanmıştır ve kriterler arasından çevresel faktörler kuruluş yerini etkileyen en önemli kriter olduğu tespit edilmiştir. Özdemir ve ark. (2018) yaptıkları çalışmada Bulanık Analitik Hiyerarşi Süreci ve Gri İlişkisel Analiz yöntemlerini bütünleşik kullanarak en iyi personeli belirlemeye çalışmışlardır.

Bu çalışmada, Muğla ilinde örtüaltı domates üreticilerinin girdi kullanım kararları ekonometrik yönden ele alınarak öncelik ve tercih kriterleri AHP yöntemiyle saptanmıştır. Üreticilerin girdi kullanımına karar vermede fiyat, pazarlama ve verim kriterlerini dikkate alarak işgücü, mazot, fide, pestisit, gübre, BGD, tuzak ve su girdilerinden hangilerini tercih ettikleri değerlendirilmiştir. Bunun yanı sıra, üreticilerin girdi kullanım tercihine karar vermede kimyasal ve organik kriterlerini dikkate alarak fiyat, verim, pazarlama, destekleme ve ulaşılabilirlik alternatiflerinin öncelikleri incelenmiştir.

\section{Materyal ve Yöntem}

Araştırmanın materyalini Muğla iline bağlı Seydikemer, Fethiye ve Ortaca ilçelerinde örtüaltında domates yetiştiren üreticilerden anket yöntemiyle elde edilen veriler oluşturmuştur. Ayrıca Türkiye'de ve diğer ülkelerde daha önce yapılan araştırmalardan elde edilen bilgilerden de yararlanılmıştır. Araştırmada aşağıdaki oransal örnek hacmi formülünden yararlanılmış (Newbold 1995) ve \%95 güven aralığı ile \%10 hata payı esas alınarak örnek hacmi 93 olarak belirlenmiştir.

$$
n=\frac{N p(1-p)}{(N-1) \sigma_{p x}^{2}+p(1-p)}
$$

Formülde;

$\mathrm{n}=$ Örnek hacmi

$\mathrm{N}=$ Toplam örtüaltı üreticisi sayısı (2869)

$\mathrm{p}=$ Örtüaltında domates yetiştiren üreticilerin oranı (maksimum örnek hacmine ulaşmak için 0.50 alınmıştır).

$\sigma_{p x}^{2}=$ Varyanstır.

Her ilçeden kapsama alınacak üretici sayısının belirlenmesinde ise, toplam üretici sayısı içerisinde ilçelerin payları esas alınmıştır. Bu yaklaşımla ilçelerden araştırma kapsamına alınacak üretici sayıları Seydikemer ilçesinde 52, Fethiye ilçesinde 27 ve Ortaca ilçesinde 14 üretici olarak hesaplanmıştır. Araştırma anketleri Şubat ve Mart 2016'da gerçekleştirilmiştir.
Araştırmada örtüaltı domates üreticilerinin girdi kullanım kararları ekonomik açıdan karar hiyerarşisi halinde ele alınmıştır. AHP kullanılarak hangi kriterlere hangi düzeyde öncelik verileceği belirlenmiştir. AHP, birden çok kriter içeren karmaşık problemlerin çözümünde kullanılan bir karar verme yöntemidir. Karar vericilere, karmaşık problemleri, problemin ana hedefi, kriterleri, alt kriterleri ve seçenekleri arasındaki ilişkiyi gösteren bir hiyerarşik yapıda modelleme olanağ vermektedir (Saaty ve ark. 2003). Kisaca, karar problemi hiyerarşik bir yapıya ayrıştırılır. Karar problemini temel bileşenlerine ayrıştırmak ve hiyerarşik bir yapı oluşturmak, karar vericiye, ilgili kararın daha küçük parçaları üzerinde odaklanmasına yardımcı olur (Braunschweig ve Becker 2004). Kriterlerin hiyerarşik organizasyonu, büyük karar problemlerinde yaygın olarak kullanılmaktadır. İnsan beyninin belirli bir zamanda yedi uyarıcıdan daha fazlasını işleyemediği, aynı anda üç kriterden daha fazlasını karşılaştıramadığını kanıtlanmıştır (Prakash 2003).

AHP, ayrıştırma, eşli karşılaştırma ve hiyerarşik düzenleme olma üzere üç temel ilkeye dayanmaktadır. Ayrıştırma bir problemi, çeşitli hiyerarşiler halinde yapılandırma işlemidir. Eşli karşılaştırma, seçenekler veya kriterler için eşli karşılaştırma matrisi oluşturma sürecidir. Hiyerarşik düzenleme ise hiyerarşi üstündeki karşılaştırmaları birleştirme işlemidir (Günden ve Miran 2008a).

AHP'de öncelikle problem belirlenir ve probleme ait kriterler, alt kriterler ve alternatifler ortaya konmaktadır. Bu şekilde bir hiyerarşi oluşturulmaktadır. Hiyerarşi oluşturulduktan sonra ikili karşılaştırmalar yapılarak karşılaştırma matrisi elde edilmekte ve bu verilerden her kriterin önem derecesi belirlenmektedir. En son olarak tüm kriterler birlikte değerlendirilerek en iyi seçenek ya da en iyi sıralama ortaya konmuş olmaktadır. AHP'de çözüm adımları şu şekilde siralanmaktadır:

- Problem ortaya konmakta, hiyerarşide en üstte yer alacak hedef belirlenmektedir.

- Daha sonra hiyerarşi oluşturulmaktadır. Oluşturulan hiyerarşide; en üstte amaç olmak üzere kriterler, alt kriterler ve alternatifler belirlenmektedir.

- İkili karşılaştırma matrisi oluşturulmaktadır.

- Oluşturulan ikili karşılaştırma matrisinden yararlanarak göreli önem vektörü (ağırlık vektörü) bulunmaktadır.

- Tutarlılık oranı hesaplanmaktadır. Tutarlılık durumunda karar verilmektedir.

- Tutarlı olmama durumunda ikili karşılaştırmalar tekrar gözden geçirilerek işlemler tekrarlanmaktadır (Göksu ve Güngör 2008).

- Her seviyede üst sıralara çıkıldıkça azalma eğilimi gösteren ve bir üst sırada yer alanın amacına uygun birçok karşılaştırmadan meydana gelen, derecelendirme vazifesini gören yapıya hiyerarşi denir (Ayyıldız 2003). Hiyerarşi $n$ eleman içeriyorsa, toplam $\mathrm{n}(\mathrm{n}-1) / 2$ adet eşli karşıllaştırma yapmak gerekmektedir. Eşli karşılaştırmada kriter 1'in kriter 2'ye göre ne kadar önemli olduğu Çizelge 1'de gösterilen 1-9 puanlı tercih ölçeğiyle belirlenmektedir (Saaty 1980; Dicle 2010). 
Çizelge 1. AHP'de kullanılan standart tercih ölçeği.

Table 1. Standard preference scale for AHP.

\begin{tabular}{lll}
\hline Önem Derecesi & Tanım & Açıklama \\
\hline 1 & Eşit önemli & İki faaliyet amaca eşit düzeyde katkıda bulunur \\
3 & Birinin diğerine göre orta & Tecrübe ve yargı bir faaliyeti diğerine orta derecede tercih ettirir \\
5 & derecede önemli olması & Tecrübe ve yargı bir faaliyeti diğerine kuvvetli bir şekilde tercih ettirir \\
7 & Kuvvetli derecede önemli & Bir faaliyet güçlü bir şekilde tercih edilir ve baskınlığı uygulamada rahatlıkla görülür \\
9 & Çok kuvvetli düzeyde önemli & Bir faaliyetin diğerine tercih edilmesine ilişkin kanıtlar çok büyük bir güvenirliliğe sahiptir \\
$2,4,5,6,8$ & Kesin derecede önemli & Uzlaşma gerektiğinde kullanılmak üzere yukarıda listelenen yargılar arasında düşen değerler \\
\hline
\end{tabular}

Kriterlerin tümü için ikili karşılaștırmalar ve karar seçeneklerinin her bir karar kriterine göre ikili karşılaştırmaları yapılmaktadır. Bu ikili karşılaştırmalardan yararlanılarak her bir kriterin ve her bir kritere göre karar seçeneklerinin alternatif öncelikleri hesaplanmaktadır. İki kriterin ya da karar seçeneklerinin karşılaştırılmasında bir kriterin karşılaştırma değeri $\mathrm{x}$ ise diğer kriter için bunun karşılaştırma değeri 1/x'dir. Karşılaştırmalarda oluşturulan matris (A) aşağıdaki gibi ifade edilmektedir (Saaty 1986; Saaty 1990; Çobanoğlu ve Işın 2009):

$$
A=\left[a_{i j}\right]_{n x n}
$$

Matriste kriterler kendisiyle karşılaştırılıyorsa ' 1 ' değerini almaktadır. Çiftlerin karşılaştırılamayacağı anlamına geldiği için ' 0 ' kullanılmamalıdır. Puan verilirken pozitif değerlerin kullanılması gerekmektedir.

Önem vektörü hesaplanırken öncelikle ikili karşılaştırmalar matrisinden;

$$
b_{i j}=\frac{a_{i j}}{\sum_{i=1}^{n} a_{i j}}
$$

Formülü ile B matrisi elde edilmektedir:

$$
B=\left[b_{i j}\right]_{n x n}
$$

B matrisinden de;

$$
w_{i}=\frac{\sum_{J=1}^{n} b_{i j}}{n}
$$

Formülü ile kriterlerin ağırlık vektörü hesaplanmaktadır:

$$
k W=\left[w_{i}\right]_{n x 1}
$$

$\mathrm{Bu}$ işlemler her bir karar kriterine göre karar seçenekleri için de tekrarlanmaktadır. Her bir karar kriterine göre karar seçeneklerinin ağırlık puanları bir araya getirildiğinde karar seçeneklerinin ağırlık puanları matrisi elde edilmektedir:

$$
s W=\left[W_{i j}\right]_{n x m}
$$

Karar kriterlerinin ağırlık puanları vektörü ile karar seçeneklerinin ağırlık puanları matrisinin çarpımılla da karar seçeneklerinin toplam puanlarına ulaşılmaktadır:

$$
W=\left[w_{i}\right]_{n x 1} *\left[w_{i j}\right]_{n x m}
$$

\section{Bulgular}

Araştırmanın bu bölümünde üreticilerin örtüaltı domates üretiminde girdi kullanımında ve girdi kullanım tercihinde (kimyasal ve organik) dikkate aldığ AHP'den yararlanılmıştır. AHP uygulamasında sonuçların tutarlı olması için görüşülen kişilerin konularında uzman olması tercih edilmektedir. Araştırmada üreticilerle görüşüldüğ̈̈ için tutarlılık oranı hesaplanmamıştır. Araştırmada AHP kriterlerini belirlemek amacıyla Şekil 1'deki ve Şekil 2'deki karar ağacı oluşturulmuştur.

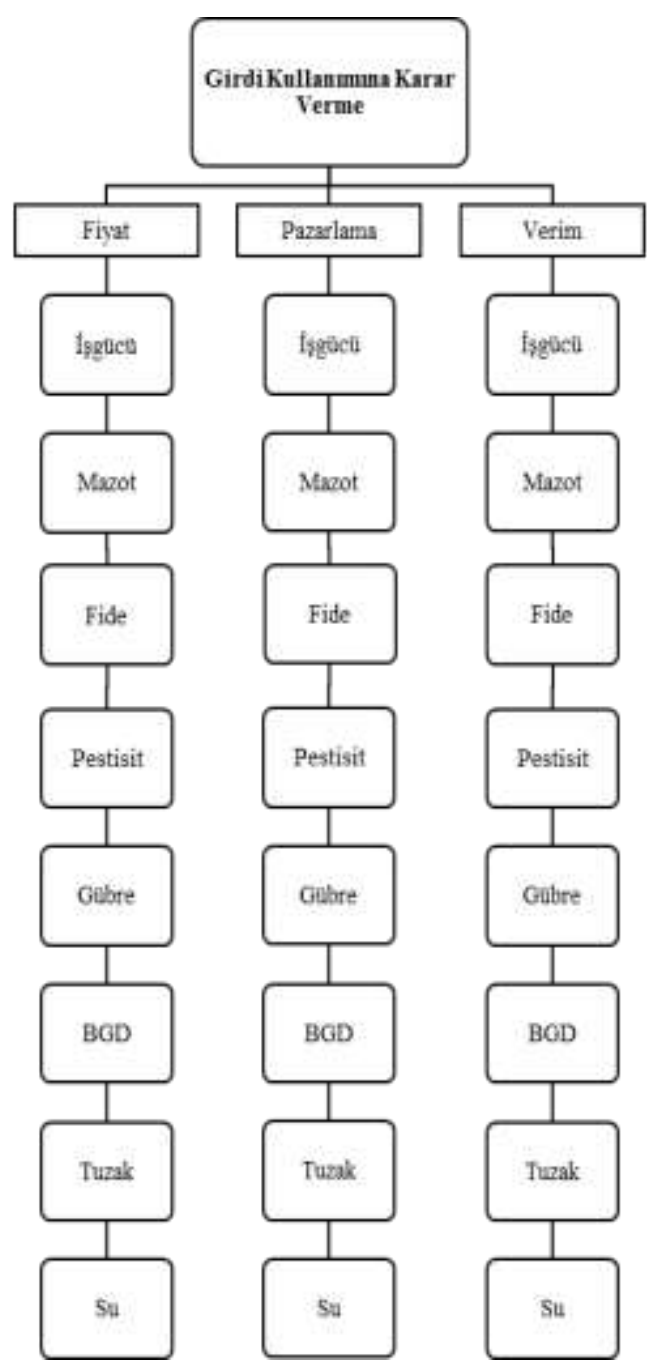

Şekil 1. AHP girdi kullanımı karar ağacı.

Figure 1. AHP input usage decision tree. 


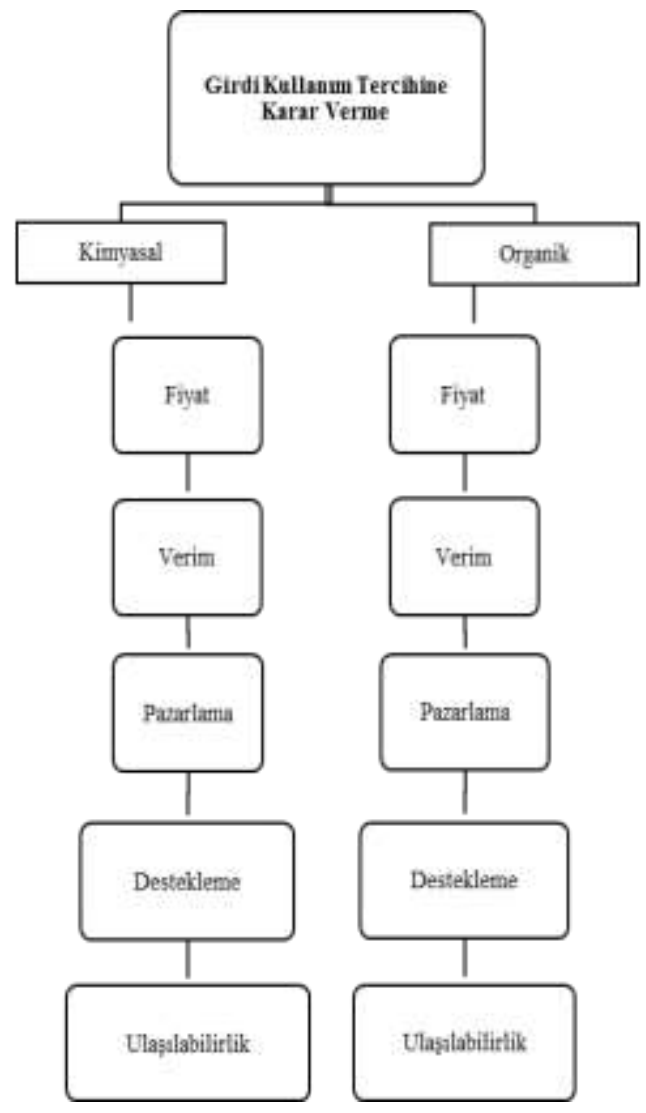

Şekil 2. AHP girdi kullanım tercihi karar ağacı.

Figure 2. AHP preferences of input usage decision tree.

Girdi kullanım kararlarının değerlendirilmesinde fiyat kriterinin seçenekleri içinde önem değeri en yüksek değer fide (0.298), daha sonra sirasiyla gübre (0.186), pestisit (0.142), mazot (0.123), su (0.114), BGD (0.077), işgücü (0.073) ve tuzak (0.054) olarak hesaplanmıştır (Çizelge 2).

Girdi kullanım kararlarının değerlendirilmesinde pazarlama kriterinin seçenekleri içinde önem değeri en yüksek değer fide (0.305) olarak saptanmıştır. Bunu sırasıyla gübre (0.182), pestisit (0.141), mazot (0.118), işgücü (0.113), su (0.082), BGD (0.058) ve tuzak (0.053) izlemektedir (Çizelge 3). Friedman testi sonuçlarına göre tercihler arasında istatistiksel olarak anlamlı bir fark bulunmuştur ( $\mathrm{p}=0.000)$.

Girdi kullanım kararlarının değerlendirilmesinde verim kriterinin seçenekleri içinde önem değeri en yüksek fide (0.275) hesaplanmış olup, bunu sirasıyla işgücü (0.204), gübre (0.143), pestisit (0.123), mazot (0.101), tuzak (0.074), su (0.061), ve BGD (0.060) izlemektedir (Çizelge 4). Friedman testi sonuçlarına göre tercihler arasında istatistiksel olarak anlamlı bir fark bulunmuştur $(\mathrm{p}=0.000)$.

Örtü altı domates üretiminde etkili olan kriterlerin önem dereceleri incelendiğinde; üreticiler için fiyatın (0.462) en önemli kriter olduğu, daha sonra pazarlama kriteri (0.293) geldiği ve bunu verim kriterinin (0.245) izlediği görülmektedir (Çizelge 5). Kruskal Wallis testine göre kriterlere verilen öncelikler arasında istatistiksel olarak anlamlı bir fark vardır $(p=0.046)$. Bu sonuca göre girdi kullanımıyla ilgili etkili olan kriterlerden en az birinin diğerlerine tercih edildiğini söylemek mümkündür.
Çizelge 2. Üreticilerin fiyat açısından girdi kullanım kararlarının değerlendirilmesi.

Table 2. Evaluation of input usage decisions of farmers according to price

\begin{tabular}{lcccc}
\hline Seçenekler & Ortalama & Std. sapma & Min. & Maks. \\
\hline İşücü & 0.073 & 0.079 & 0.007 & 0.290 \\
Mazot & 0.123 & 0.135 & 0.014 & 0.670 \\
Fide & 0.298 & 0.100 & 0.064 & 0.380 \\
Gübre & 0.186 & 0.053 & 0.057 & 0.366 \\
İlaç & 0.142 & 0.054 & 0.009 & 0.366 \\
Tuzak & 0.054 & 0.046 & 0.007 & 0.195 \\
BGD & 0.077 & 0.042 & 0.007 & 0.237 \\
Su & 0.114 & 0.064 & 0.007 & 0.365 \\
\hline Friedman testi $\mathrm{p} \leq 0.01$ için anlamlıdr. Kendall's $\mathrm{W}: 0.000$. &
\end{tabular}

Friedman testi $\mathrm{p} \leq 0.01$ için anlamlıdır. Kendall's W: 0.000 .

Çizelge 3. Üreticilerin pazarlama açısından girdi kullanım kararlarının değerlendirilmesi.

Table 3. Evaluation of input usage decisions of farmers according to marketing.

\begin{tabular}{lcccc}
\hline Seçenekler & Ortalama & Std. sapma & Min. & Maks. \\
\hline İşücü & 0.113 & 0.079 & 0.009 & 0.365 \\
Mazot & 0.118 & 0.059 & 0.029 & 0.380 \\
Fide & 0.305 & 0.100 & 0.050 & 0.377 \\
Gübre & 0.182 & 0.049 & 0.055 & 0.347 \\
İlaç & 0.141 & 0.042 & 0.032 & 0.364 \\
Tuzak & 0.053 & 0.040 & 0.007 & 0.252 \\
BGD & 0.058 & 0.045 & 0.006 & 0.235 \\
Su & 0.082 & 0.073 & 0.007 & 0.365 \\
\hline Friedman testi $\mathrm{p} \leq 0.01$ için anlamlıdır. Kendall's W: 0.000 &
\end{tabular}

Çizelge 4. Üreticilerin verim açısından girdi kullanım kararlarının değerlendirilmesi.

Table 4. Evaluation of input usage decisions of farmers according to yield.

\begin{tabular}{lcccc}
\hline Seçenekler & Ortalama & Std. sapma & Min. & Maks. \\
\hline İsücü & 0.204 & 0.092 & 0.013 & 0.365 \\
Mazot & 0.101 & 0.074 & 0.008 & 0.356 \\
Fide & 0.275 & 0.101 & 0.054 & 0.366 \\
Gübre & 0.143 & 0.037 & 0.058 & 0.373 \\
İlaç & 0.123 & 0.044 & 0.033 & 0.365 \\
Tuzak & 0.074 & 0.041 & 0.007 & 0.365 \\
BGD & 0.060 & 0.038 & 0.013 & 0.235 \\
Su & 0.061 & 0.069 & 0.007 & 0.365 \\
\hline
\end{tabular}

Friedman testi $\mathrm{p} \leq 0.01$ için anlamlıdır. Kendall's W: 0.000 .

Çizelge 5. Üreticilerin örtüaltı domates üretiminde fiyat, verim ve pazarlama kriterlerine verdiği önem düzeyleri.

Table 5. The level of importance given to price, yield and marketing criteria by farmers in greenhouse tomato production.

\begin{tabular}{lcccc}
\hline Kriterler & Ortalama & Std. sapma & Min. & Maks. \\
\hline Fiyat & 0.462 & 0.282 & 0.051 & 0.727 \\
Verim & 0.245 & 0.176 & 0.051 & 0.727 \\
Pazarlama & 0.293 & 0.300 & 0.052 & 0.727 \\
\hline
\end{tabular}

Üreticiler kimyasal girdi kullanırken göz önüne aldığı seçenekler önem düzeyine göre sıralandığında verim (0.350) ilk sirada yer almakta, bunu sirasiyla fiyat $(0.281)$, destekleme 
(0.162), pazarlama (0.146), ve ulaşılabilirlik (0.061) izlemektedir (Çizelge 6). Friedman testi sonuçlarına göre tercihler arasında istatistiksel olarak anlamlı bir fark vardır $(\mathrm{p}=0.000)$.

Üreticiler organik girdi kullanırken göz önüne aldığ1 seçenekler önem düzeyine göre sıralandığında fiyat (0.370) ilk sirada yer almakta, bunu sirasiyla verim (0.320), pazarlama (0.132), destekleme (0.110), ve ulaşılabilirlik (0.069) izlemektedir (Çizelge 7). Friedman testi sonuçlarına göre tercihler arasında istatistiksel olarak anlamlı bir fark vardır $(p=0.000)$. Bu sonuca göre organik girdi kullanımı kararlarıyla ilgili bazı seçeneklerin diğerlerinin üzerinde tercih edildiğini söylemek mümkündür.

Üreticiler girdi kullanım tercihinde önceliği kimyasal girdilere (0.571) vermektedir (Çizelge 8). Mann Whitney U testine göre öncelikler arasında istatistiksel olarak anlamlı bir fark bulunmamaktadır $(\mathrm{p}=0.271)$.

Çizelge 6. Üreticilerin kimyasal girdi kullanım kararlarının değerlendirmesi.

Table 6. Evaluation of chemical input usage decisions of farmers.

\begin{tabular}{lcccc}
\hline Seçenekler & Ortalama & Std. sapma & Min. & Maks. \\
\hline Fiyat & 0.281 & 0.150 & 0.024 & 0.525 \\
Verim & 0.350 & 0.141 & 0.012 & 0.519 \\
Destekleme & 0.162 & 0.098 & 0.012 & 0.519 \\
Pazarlama & 0.146 & 0.110 & 0.062 & 0.519 \\
Ulaşlabilirlik & 0.061 & 0.102 & 0.012 & 0.519
\end{tabular}

Friedman testi $\mathrm{p} \leq 0.01$ için anlamlıdır. Kendall's W: 0.000 .

Çizelge 7. Üreticilerin organik girdi kullanım kararlarının değerlendirmesi.

Table 7. Evaluation of organic input usage decisions of farmers.

\begin{tabular}{lcccc}
\hline Seçenekler & Ortalama & Std. sapma & Min. & Maks. \\
\hline Fiyat & 0.370 & 0.168 & 0.025 & 0.525 \\
Verim & 0.320 & 0.150 & 0.023 & 0.519 \\
Destekleme & 0.110 & 0.062 & 0.012 & 0.258 \\
Pazarlama & 0.132 & 0.092 & 0.074 & 0.528 \\
Ulaşllabilirlik & 0.069 & 0.089 & 0.012 & 0.519 \\
\hline Friedman testi $\mathrm{p} \leq 0.01$ icin anlamlıdır. Kendall's W: 0.000 & &
\end{tabular}

Çizelge 8. Üreticilerin girdi kullanım önceliklerinin değerlendirmesi. Table 8. Evaluation of input usage priorities of farmers.

\begin{tabular}{lcccc}
\hline Kriterler & Ortalama & Std. sapma & Min. & Maks. \\
\hline Kimyasal & 0.571 & 0.386 & 0.100 & 0.900 \\
Organik & 0.429 & 0.386 & 0.100 & 0.900 \\
\hline
\end{tabular}

Tokat ilinde sırık ve yer domatesi üretiminde üreticilerin fiyat, verim, pazarlama, maliyet ve sürdürülebilirlik kriterleri açısından karar önceliklerinin belirlendiği bir araştırmada sırık domates üretimini fiyat, verim ve pazarlama kriterlerinde öncelikle öneme ve sırık domates üretiminin yer domatesi üretimine göre \%61 puan ile öncelikli öneme sahip olduğu belirlenmiştir (Dal ve Kızılaslan 2013). Yalova ilinde kesme çiçek üreticilerinin kullanım etkinliği, temin kolaylığ 1 ve fiyat kriterleri açısından kullandıkları girdiler açısından karar önceliklerinin belirlendiği bir çalışmada ise kullanım etkinliği açısından; önceliği ilk olarak soğana, daha sonra sirasıyla fide, su ve pestisite verdiği, temin kolaylığı açısından; önceliği suya, daha sonra sırasıyla perlit ve torfa verdiği, fiyat açısından; önceliği soğana, daha sonra sırasiyla fide, gübre, pestisit ve işgücüne verdiği tespit edilmiştir (Öztürk 2012). Yapılan bir araştırmada Trakya'da üreticilerin girdi kullanımında önceliğin hangi girdide yoğunlaştığı ve her bir girdinin uygulama kararı alınmasında bilgi alınacak kişi ya da kurum öncelik sıraları belirlenmiştir. Araştırmada üreticilerin tohum kullanımı, gübre kullanımı ve pestisit kullanımı konusunda öncelikle ziraat mühendislerine danıştıkları saptanmıştır (Aydın ve ark. 2016).

\section{Sonuç}

Çalışmada Muğla ilinde örtüaltında domates yetiştiren üreticilerin girdi kullanımına karar verme süreçlerini incelemek amaciyla çok kriterli karar verme yöntemlerinden AHP kullanılmıştır. Üreticilerin girdi kullanım kararını etkileyen kriterlere verdikleri öncelikler ile kriterlerin seçeneklerine verdikleri önem değerleri saptanmıştır. Örtüaltı domates üretiminde üreticilerin girdi kullanım kararında en fazla etkili olan kriterin fiyat olduğu tespit edilmiştir. Bunu ikinci sırada pazarlama kriteri ve üçüncü sırada verim kriteri izlemektedir. Buna göre üreticiler girdi kullanımında girdi fiyatlarını daha çok önemsemektedir. Daha uygun fiyatlı girdi temini ve pazarlamada etkinlik sağlamak için üreticilerin örgütlenmesi teşvik edilmelidir. Ayrıca üreticiler, öncelikle mevcut ve potansiyel pazarları araştırmalı ve bu pazarların talebine uygun olarak üretimlerini yönlendirmelidir. Dolayısıyla üretimden önce pazar araştırmaları yapılmalıdır. Üreticiler girdi kullanımına karar verirken fiyat, verim ve pazarlama kriterlerinde dikkate aldıkları en önemli girdinin fide olduğu saptanmıştır. Örtü altında güvenli ve kaliteli domates üretimi için fide seçimi en önemli noktalardan biridir. Fide seçiminde verim düzeyi ve hastalık ve zararlılara karşı dayanıklılık dikkate alınmalıdır. Aşılı fidelerin fungus hastalıklarına dayalı olması nedeniyle son dönemlerde üreticiler aşılı fide kullanımını tercih etmektedirler. Özellikle pestisit kullanımının azaltılması için aşılı fide kullanımın yaygınlaştırılması ve üreticilerin aşılı fide kullanımının yararları konusunda bilgilendirilmesi gerekmektedir. Bununla birlikte, üreticilerin gerektiği kadar girdi kullanılması yönünde bilinçlendirilmesi, örtü altında sağlıklı ve çevreye zarar vermeyen ürünlerin aynı zamanda kârlı bir şekilde üretilmesini de sağlayacaktır.

\section{Kaynaklar}

Aguilar-Lasserre A, Bautista Bautista MA, Ponsich A, Gonzàlez Huerta MA (2009) An AHP-based decision-making tool for the solution of multiproduct batch plant design problem under imprecise demand. Computers \& Operations Research 36(3): 711-736.

Ahn BS, Choi SH (2008) ERP system selection using a simulationbased AHP approach: a case of Korean homeshopping company. Journal of the Operational Research Society 59(3): 322-330.

Arslan T (2009) A hybrid model of fuzzy and AHP for handling public assessments on transportation projects. Transportation 36(1): 97112.

Arslan ET (2010) Analitik hiyerarşi süreci yöntemiyle strateji seçimi: Süleyman Demirel Üniversitesi İktisadi ve İdari Bilimler Fakültesinde bir uygulama. Süleyman Demirel Üniversitesi İktisadi ve İdari Bilimler Fakültesi Dergisi 15(2): 455-477.

Aydın B, Unakıtan G, Hurma H, Azabağaoğlu Ö, Demirkol C, Yılmaz F (2016) Bitkisel üretimde çiftçilerin girdi kullanım kararlarının analizi: Trakya Bölgesi örneği. Uludağ Üniversitesi Ziraat Fakültesi Dergisi 30(2): 45-56.

Ayyıldız G (2003) CIM yatırımlarının bulanık AHP yöntemi ile değerlendirilmesi. Yüksek Lisans Tezi, İstanbul Teknik Üniversitesi Fen Bilimleri Enstitüsü, İstanbul. 
Bostancıoğlu E, Önder NP (2018) Applying analytic hierarchy process to the evaluation of double skin façades. Architectural Engineering and Design Management 15(1): 66-82.

Braunschweig T, Becker B (2004) Choosing research priorities by using the analytic hierarchy process: an application to international agriculture. R\&D Management 34(1): 77-86.

Büyüközkan G (2012) An integrated fuzzy multi-criteria group decision-making approach for green supplier evaluation. International Journal of Production Research 50(11): 2892-2909.

Çobanoğlu F, Işın F (2009) Organik kuru incir üreticilerinin organik tarım sistemi tercihini etkileyen kriterlerin analitik hiyerarşi süreci ile analizi. Tarım Ekonomisi Dergisi 15(2): 63-71.

Dal B, Kızılaslan H (2013) Analitik hiyerarşi yaklaşımı ile üretici kararlarının analizi (Tokat ili domates üreticileri örneği). Gaziosmanpaşa Bilimsel Araştırma Dergisi 8(2013): 29-39.

Dicle M (2010) İzmir ili Bornova ilçesinde tıbbi bitkilere ilişkin tüketici davranışlarının belirlenmesi üzerine bir araştırma. Yüksek Lisans Tezi, Ege Üniversitesi Fen Bilimleri Enstitüsü, İzmir.

Göksu A, Güngör İ (2008) Bulanık analitik hiyerarşik proses ve üniversite tercih sıralamasında uygulanması. SDÜ İktisadi ve İdari Bilimler Fakültesi Dergisi 13(3): 1-26.

Günden C, Miran B (2008a) Çiftçilerin temel işletmecilik kararlarının öncelik ve destek alma açısından analizi. Tekirdağ Ziraat Fakültesi Dergisi 5(2): 67-80.

Günden C, Miran B (2008b) Bulanık analitik hiyerarşi süreci kullanılarak çiftçi kararlarının analizi. Ege Üniversitesi Ziraat Fakültesi Dergisi 45(3): 195-204.

Günden C (2016) Kıyı Ege Havzasında çiftçilerin üretim dalı tercihleri ve tarım politikaları. Ege Üniversitesi Ziraat Fakültesi Dergisi 53(4): 451-459.

Işın Ş (2000) Bayes kuralının tarımsal işletmecilik kararlarında uygulanışına bir örnek. Tarım Ekonomisi Dergisi 5: 61-70.

Korpela J, Lehmusvaara A, Nisonen J (2007) Warehouse operatör selection by combining AHP and DEA methodologies. International Journal of Production Economics 108(1-2): 135-142.
Newbold P (1995) Statistics for Business and Economics. PrenticeHall, New Jersey.

Ömürbek N, Üstündağ S, Helvacioğlu ÖC (2013) Kuruluş yeri seçiminde analitik hiyerarşi süreci (AHP) kullanımı: Isparta Bölgesi’nde bir uygulama. Yönetim Bilimleri Dergisi 11(21): 101116.

Özdemir Y, Nalbant KG, Başlıgil H (2018) Personnel selection for promotion using an integrated fuzzy analytic hierarchy processgrey relational analysis methodology: a real case study. Anadolu University Journal of Science and Technology A- Applied Sciences and Engineering 19(2): 278-292.

Öztürk M (2012) Yalova ili kesme çiçek üreticilerinin üretim ve girdi kullanım kararları üzerine bir araştırma. Doktora Tezi, Ege Üniversitesi Fen Bilimleri Enstitüsü, İzmir.

Prakash TN (2003) Land suitability analysis for agricultural crops: a fuzzy multicriteria decision making approach. International Institute for Geo-Information Science and Earth Observation, Enschede, The Netherlands.

Quezada LE, López-Ospina HA (2014) A method for designing a strategy map using AHP and linear programming. International Journal of Production Economics 158: 244-255.

Saaty TL (1980) The Analytic Hierarchy Process: Planning, Priority Setting, Resource Allocation. McGraw- Hill, Newyork.

Saaty TL (1986) Axiomatic foundations of the analytic hierarchyprocess. Management Science 32(7): 841-855.

Saaty TL (1990) How to make a decision: the analytic hierarchy process. European Journal of Operational Research 48(1): 9-26.

Saaty TL, Vargas LG, Dellmann K (2003) The allocation of intangible resources: the analytic hierarchy process and linear programming. Socio-Economic Planning Sciences 37: 169-184. 